\title{
Study of Generator Set Overload Protection System in Power Generation Units
}

\begin{abstract}
Bambang Winardi \& Agung Nugroho
Abstract- The need for electrical energy in an industry is very important for the production process to run. To meet the demand for electrical energy, one can use a power source from PLN or use an independent power source by establishing a power plant. The Power Plant Unit is a unit that functions to provide electrical energy needs for the production process at PPSDM Migas. Electricity generation in the Power Plant Unit, namely Pembangkit Listrik Tenaga Diesel (PLTD) using a generator set that uses diesel fuel. A generator set or generator is a generator that has been equipped with a prime mover. Gensets that work continuously are certainly inseparable from disturbances such as the occurrence of overloads. Overload disturbance occurs because the amount of load power supplied by the generator is greater than the capacity of the working generator. Air Circuit Breaker (ACB) is one of the protective equipment used to protect generator sets. Inside the ACB there is Over Current Trip equipment that will work if there is an overload on the generator. The capacity of the generator used is $1000 \mathrm{kVA} / 400 \mathrm{~V}$ with a nominal generator current of $1443.38 \mathrm{~A}$. Under normal load conditions, the installed load power is $354.5 \mathrm{~kW}$ with a load current of $639.6 \mathrm{~A}$. Then at peak load conditions, the installed load power is $510,3 \mathrm{~kW}$ with a load current of $920.7 \mathrm{~A}$. In both conditions the load current does not exceed the nominal current of the generator so Over Current Trip does not instruct ACB to trip. However, it is possible for overload disturbances to occur if there is no coordination between the operator at the power plant and the load operator (refinery \& utilities) so that the operation of the load is not controlled.
\end{abstract}

Keywords: Generator Set, Overload, ACB, Over Current Trip, Power Plant, Overload, Prime Mover

\section{INTRODUCTION}

$\mathrm{T}$ The generating unit is a unit that handles the supply of electricity needs at PPSDM Migas. The generating unit at PPSDM Migas uses a Diesel Power Plant (PLTD) to generate electricity. The electricity produced is used to supply the needs of a power source for equipment located in refineries and utilities. [1,2]

The power generation unit has 4 generators to generate electricity. Genset 1 has a capacity of $1000 \mathrm{kVA} / 400 \mathrm{~V}$, and generator 2 has a capacity of $1030 \mathrm{kVA} / 400 \mathrm{~V}$, generator 8 has a capacity of $1000 \mathrm{kVA} / 400 \mathrm{~V}$ and generator 9 has the smallest capacity of $640 \mathrm{kVA} / 400 \mathrm{~V}$. The power plant in PPSDM Migas uses a Single Operation system where only 1 generator operates while the others are on standby to operate according to a predetermined schedule. Genset (genset) is a generator that has been equipped with with prime mover. Genset too Routine maintenance should be performed every 250 hours after surgery.[3]

Generators that work continuously, of course, cannot be separated from disturbances that can damage the generator if left alone. Therefore, a reliable protection system is needed to prevent this. The protection system consists of several components that are interconnected and work together for security purposes. [3,4]

- Bambang Winardi, Department of Electrical Engineering, Diponegoro University, Semarang Indonesia, PH-081326315664. E-mail: bbwinar@gmail.com

- Agung Nugroho, Department of Electrical Engineering, Diponegoro University, Semarang Indonesia, PH-085225036502. E-mail: agung.nugroho@gmail.com

\section{Research Method}

2.1 Studying the generator set protection system, the Air Circuit Breaker $(\mathrm{ACB})$ work system and setting the $\mathrm{ACB}$ Over Current Trip as an overload protection system for the generator set in the Power Plant Unit

\subsection{Protection System}

1. What is meant by protection against electric power is a security system carried out on electrical equipment, which is installed on the electric power system. For example generators, transformers, transmission /distribution networks and others against abnormal conditions of the system itself.

2. What is meant by abnormal conditions are, among others, in the form of:

- Short circuit

- Voltage less/over

- Overload

- System frequency down/up

- And others

\section{Results and Discussion}

\subsection{Generator Set in PPSDM Migas Power Plant Unit}

The power plant unit has 4 generator sets for generating electricity. Generator 1 has a capacity of $1000 \mathrm{kVA} / 400 \mathrm{~V}$, and generator 2 has a capacity of $1030 \mathrm{kVA} / 400 \mathrm{~V}$, generator 8 has a capacity of $1000 \mathrm{kVA} / 400 \mathrm{~V}$ and generator 9 has the smallest capacity of $640 \mathrm{kVA} / 400 \mathrm{~V}$. Power generation at PPSDM Migas uses Single Operation system where only 1 generator operates while the others are in standby to operate according to a predetermined schedule. Gensets must also be routinely maintained every 250 hours after operating. 


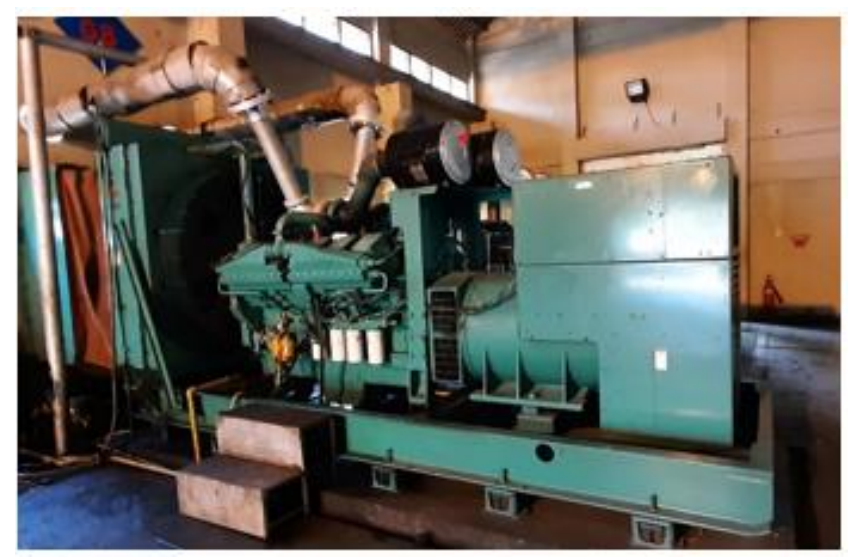

Figure 1 Generator Set 8 in the PPSDM Migas power plant unit

In the process of working, the diesel engine rotates the rotor inside the generator which will cause a magnetic field in the generator coil. Furthermore, this magnetic field will then interact with the rotor which will then rotate and produce an electric current.

\subsection{Generator Overload Protection System in PPSDM Migas Power Plant Unit}

Due to the importance of a protection system to prevent damage and loss of electrical equipment, PPSDM Migas uses ACB (Air Circuit Breaker) as one of the protection systems used to protect the generator set in the power plant unit. The following is the ACB used for the generator protection system 8 in the Power Plant Unit

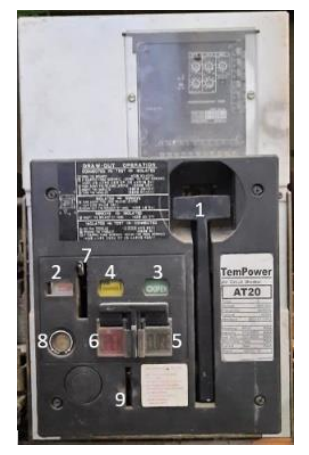

Figure 2 Air Circuit Breaker (ACB) Genset 8 in the Power Plant Unit they are part of a sentence, as in

\section{Description:}

1. Charging handle

This handle is inflated to manually fill the closing spring. It is also used for slow closing operations.

2. Position Indicator

Displays the words "CONN", "TEST", or "ISOLATED" according to the condition of the ACB

3. OPEN-CLOSED Indicator
Shows the word "OPEN" when the breaker is in an open circuit, and "CLOSED" when the breaker is in a closed circuit.

4. Spring charge indicator Shows the word "CHARGED" when the cover spring is fully charged and "DISCHARGE" when released.PUSH TO CLOSE button

Pressing this button will close the breaker.

\section{PUSH TO OPEN}

Pressing this button will open the breaker.

\section{Position stopper release lever}

When this lever is in the up position, the breaker locks in the CONN, TEST, and ISOLATED positions respectively. This lever can only be changed if the breaker is OPEN. Lowering this lever unlocks the position.

3. Draw-out handle insertion hole

A pull handle is included here. This hole is equipped with a shutter, which opens when the stop release lever is lowered.

4. Open position padlock lever (optional)

The breaker can be locked in the OPEN position. To lock the breaker in the OPEN position, press the PUSH TO OPEN button and pull the lever out, then place up to three locks on the lever. Under this padlock condition, the breaker is prevented from closing manually or electrically

Table 1

Specifications for Air Circuit Breaker (ACB) Genset 8

\begin{tabular}{lll}
\hline No & Name/Amount & Description \\
\hline 1 & Merk & TemPower \\
2 & Type & AT20 \\
3 & Pole & 3 \\
4 & Voltage & $660 \mathrm{VAC}$ \\
5 & Frekuensi & $50 / 60 \mathrm{~Hz}$ \\
6 & Current & $2000 \mathrm{~A}$ \\
\hline
\end{tabular}

To activate the Air Circuit Breaker can be done by following these steps:

- Pump the ACB with the charging handle down about 105o several times until you hear a "click" sound and the spring charged indicator will show "CHARGED".

- Then press the PUSH TO CLOSED button which will cause the $\mathrm{ACB}$ to be $\mathrm{ON}$.

- When the ACB is ON, the OPEN-CLOSED indicator will show "CLOSED" and the spring charged indicator will show "DISCHARGED".

Then to disable the Air Circuit Breaker can be done by following these steps:

- Press the PUSH TO OPEN button which will cause the ACB to OFF or trip.

- When the ACB is OFF, the OPEN-CLOSED indicator will show "OPEN" and the spring charged indicator will show “DISCHARGED". 


\subsection{Setting Range Over-Current Trip}

LTD (Long Time Delay Trip) causes the breakers to wait some time to allow current to enter while, as encountered when starting a motor, current passes without tripping.

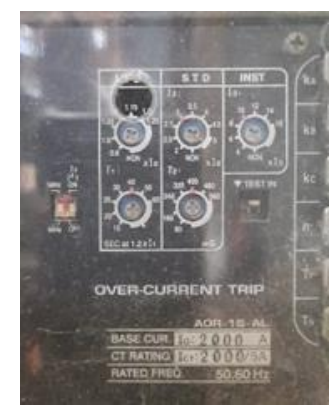

Figure 3 Setting Range Over-Current Trip

Setting range LTD (Long Time Delay Trip)

- For current I1

Settings are scaled in multiples of I0. There are 8 setting positions: NON, $0.8,1.0,1.05,1.1,1.15,1.2$, and 1.25 times I0 setting.

The CB will trip in the range of $95 \%$ to $105 \%$ of the I1 setting. (Operation tolerance: setting $\pm 5 \%$ ).

Note: when set to NON, the protection function does not work.

- For Time [T1]

Settings are scaled in seconds, showing operating time at $120 \%$ x I1 current flow.

There are 10 discrete setting positions: $15,20,25,30,35$, $40,45,50,55$, and 60 seconds. (tolerance: setting $\pm 15 \%$ ).

\subsection{Generator Analysis Against Overload}

Protection against overload is to avoid the occurrence of overloads supplied by the generator. To avoid overload, the first thing to do is to calculate the capacity of the generator with the total amount of load power to be supplied.

Generators produced by a factory will be equipped with a nameplate containing the specifications of the generator. The following are the specifications for generator 8 in the PPSDM Migas Power Plant Unit obtained from the generator nameplate.

Table 2

Generator Specifications

\begin{tabular}{lll}
\hline No & Name/Amount & Description \\
\hline 1 & Merk & ONAN \\
2 & Type & $880 \mathrm{DF}$ JD \\
3 & Capacity & $1000 \mathrm{kVA}$ \\
4 & Frequency & $50 \mathrm{~Hz}$ \\
5 & Voltage & $400 \mathrm{Volt}$ \\
6 & Phase & 3 \\
7 & Power Factor & 0.8 \\
8 & Years & 1997
\end{tabular}

DOI: $\underline{\text { https://doi.org/10.53893/ijrvocas.v1i4.67 }}$

\subsection{Calculation of Total Power Load at PPSDM Oil \& Gas Refinery \& Utilities}

In this study, 2 conditions of the load supplied during production at the Refinery \& Utilities will be discussed, namely:

1) Normal load condition

2) Peak load condition

Table 3

Total Power Data Normal Load Condition

\begin{tabular}{clcc}
\hline No & \multicolumn{1}{c}{ Load } & location & $\begin{array}{c}\text { Power } \\
(\mathbf{k W})\end{array}$ \\
\hline 1 & P. Refux C1 & Kilang & 15 \\
2 & P. Refux C2 & Kilang & 15 \\
3 & P. Feed 100/3 & Kilang & 30 \\
4 & P.Fuel 100/9 & Kilang & 11 \\
5 & Kompresor 2 & Boiler & 45 \\
6 & Air dryer 1 & Boiler & 4 \\
7 & P.1A & WPS & 75 \\
8 & P.2A & WPS & 75 \\
9 & P. Raw Water 3 & P.Plant & 5,5 \\
10 & Exhaust Fan & P.Plant & 0,75 \\
11 & Exhaust Fan & P.Plant & 0,75 \\
12 & Charger battery & P.Plant & 1 \\
13 & Charger battery & P.Plant & 1 \\
14 & Charger battery & P.Plant & 1 \\
15 & Rectifier & P.Plant & 3 \\
& Fan motor Cooling & P.Plant & 1,5 \\
16 & Tower & P.Plant & 20 \\
17 & Lighting and AC & Kilang & 50 \\
18 & Lighting and AC & Boiler & 15 \\
19 & Lighting and AC & & 354,5 \\
\hline \multicolumn{2}{r}{ total } \\
\hline
\end{tabular}

Table 4

Total Power Data Normal Load Condition

\begin{tabular}{clcc}
\hline No & \multicolumn{1}{c}{ Beban } & Lokasi & $\begin{array}{c}\text { Daya } \\
(\mathbf{k W})\end{array}$ \\
\hline 1 & P. Refux C1 & refinery & 15 \\
2 & P. Refux C2 & refinery & 15 \\
3 & P. Feed 100/3 & refinery & 30 \\
4 & P.Fuel 100/9 & refinery & 11 \\
5 & Kompresor 2 & Boiler & 45 \\
6 & Air dryer 1 & Boiler & 4 \\
7 & P.1A & WPS & 75 \\
8 & P.2A & WPS & 75 \\
9 & P. Raw Water 3 & P.Plant & 5,5 \\
10 & Exhaust Fan & P.Plant & 0,75 \\
11 & Exhaust Fan & P.Plant & 0,75 \\
12 & Charger battery & P.Plant & 1 \\
13 & Charger battery & P.Plant & 1 \\
14 & Charger battery & P.Plant & 1 \\
15 & Rectifier & P.Plant & 3 \\
& Fan motor Cooling & P.Plant & 1,5 \\
16 & Tower & P.Plant & 20 \\
17 & Lighting and AC & Kilang & 40 \\
18 & Lighting and AC & &
\end{tabular}




\begin{tabular}{|c|c|c|c|}
\hline 19 & Lighting and AC & Boiler & 10 \\
\hline 20 & $\begin{array}{l}\text { P.100/35 } \\
\text { Pertasol }\end{array}$ & refinery & 4,6 \\
\hline 21 & $\begin{array}{l}\text { P.100/36 } \\
\text { Soda }\end{array}$ & refinery & 3 \\
\hline 22 & P.100/15 Pertasol & refinery & 15 \\
\hline 23 & P.100/19 Solar & refinery & 45 \\
\hline 24 & $\begin{array}{l}\text { P.100/21 Loading } \\
\text { Residu }\end{array}$ & refinery & 45 \\
\hline 25 & P. Booster 1 & Boiler & 11 \\
\hline 26 & P. Feed 2 & Boiler & 15 \\
\hline 27 & P. Chemical 1 & Boiler & 0,55 \\
\hline 28 & $\begin{array}{l}\text { P. Blower Force draft } \\
\text { fan Boiler } 2\end{array}$ & Boiler & 15 \\
\hline 29 & P. Fuel Boiler 2 & Boiler & 2,2 \\
\hline & Jumlah & & 510,3 \\
\hline
\end{tabular}

Based on the power table under normal load conditions and peak load conditions above, the total load power supplied by generator set 8 is $354.5 \mathrm{~kW}$ and $510.3 \mathrm{~kW}$. However, the total power supplied can vary due to the output setting of the pump which is adjusted according to the needs or conditions in the field.

\subsection{Data Management for Load and Current Power}

From the existing table, it can be seen that the total load power installed at the Oil and Gas PPSDM Refinery \& Utilities is 354.5 $\mathrm{kW} 354,500$ Watt for normal load conditions and $510.3 \mathrm{~kW}$ 510,300 Watt for peak load conditions. So that the overall power needed at the Oil and Gas PPSDM Refinery \& Utilities is calculated using the equation:

1) Normal load condition

\section{Known:}

Known: $P_{\text {total }}=354.500$ watt

$$
\operatorname{Cos} \varphi=0,8
$$

So $: S_{\text {load }}=\frac{P_{\text {total }}}{\operatorname{Cos} \varphi}$

$S_{\text {load }}=\frac{354.500 \mathrm{watt}}{0,8}$

$S_{\text {load }}=443.125 \mathrm{VA}$

Meanwhile, the nominal load current can be calculated as:

$$
\begin{aligned}
I_{\text {load }} & =\frac{s}{400 \times \sqrt{3}} \\
I_{\text {load }} & =\frac{443.125}{400 \times \sqrt{3}}=\frac{443.125}{692,82}=639,6 \text { Ampere }
\end{aligned}
$$

And for the nominal current in the generator is:

$I_{\text {gen }}=\frac{1000000}{400 \times \sqrt{3}}=\frac{1000000}{692,82}=1443,38$ Ampere

Based on the calculation results, it is known that the current flowing in the load (I_load) is 639.6 A. This load current is smaller than the generator current (I_gen) which is 1443.38 A, so that the protection system on the Over-Current Trip will not command the ACB. for trips.

Peak load conditions

Known: $P_{\text {total }}=510.300 \mathrm{watt}$

$$
\operatorname{Cos} \varphi=0,8
$$

So :

$S_{\text {load }}=\frac{P_{\text {total }}}{\operatorname{Cos} \varphi}$

$S_{\text {load }}=\frac{510.300 \text { watt }}{0,8}$

$S_{\text {load }}=637.875 \mathrm{VA}$

Meanwhile, the nominal load current can be calculated as:

$I_{\text {load }}=\frac{S}{400 x \sqrt{3}}$

$I_{\text {load }}=\frac{637.875}{400 \times \sqrt{3}}=\frac{637.875}{692,82}=920,7$ Ampere

And for the nominal current in the generator is:

$I_{\text {gen }}=\frac{1000000}{400 \times \sqrt{3}}=\frac{1000000}{692,82}=1443,38$ Ampere

Based on the calculation results, it is known that the current flowing in the load (I load) is $920.7 \mathrm{~A}$. This load current is smaller than the generator current (I_gen) which is 1443.38 A, so that the protection system on the Over-Current Trip will not command the ACB. for trips.

Based on the results of the calculation of normal load conditions and peak loads above, it can be concluded that the generator set 8 can supply all loads without experiencing overload disturbances. However, it is possible for overload disturbances to occur if there is no coordination between the operator at the power plant and the load operator (refinery \& utilities) so that the operation of the load is not controlled.

\section{Conclusion}

Based on the calculation results of normal load conditions, it is known that the current flowing in the load (I_load) is 639.6 A. This load current is smaller than the generator current (I_gen) which is $1443.38 \mathrm{~A}$, so that the protection system on Over-Current Trip does not will instruct ACB to trip and Based on the calculation results of peak load conditions, it is known that the current flowing in the load (I_load) is $920.7 \mathrm{~A}$. This load current is smaller than the generator current (I_gen) which is $1443.38 \mathrm{~A}$, so the protection system on Over-Current Trip will not order ACB to trip. Based on the results of the calculation of normal load conditions and peak loads, it can be concluded that the generator set 8 can supply all loads without experiencing overload disturbances. However, it is possible for overload disturbances to occur if there is no coordination between the operator at the power plant and the load operator (refinery \& utilities) so that the operation of the load is not controlled.

\section{REFERENCES}

[1] Darma, Surya. 2017. “Analisis Sistem Proteksi Beban Lebih Pada Generator CAT.SR.4. 1000 kVA Pembangkit Tenaga 
Listrik Power Plant B Kaji Station PT.Medco E\&P Rimau Musi Banyu Asin”

[2] Efendi, Rahmat. 2020. "Studi Sistem Proteksi Generator Pada Pembangkit Listrik Tenaga Diesel Kabupaten Enrekang”.

[3] Terasaki Electric Co., Ltd. "TemPower (with PRQ) Instruction Manual-KRB 5177"

[4] F.J. Tasiam. 2017. "Proteksi Sistem Tenaga Listrik"

[5] Wayne Hartmann, 2016 Generator Protection Theory \& Application

[6] Seada Hussen 2019, Overview Of generator Protection On Power System, International Journal of Engineering Applied Sciences and Technology

[7] Muhammad Aamir Aman, 2018 Power Generator Automation, Monitoring and Protection System, J.Mech.Cont.\& Math. Sci., Vol.-13, No.-4 